Мазанаев Ш.А. Деконструкция постмодернизма и зарождение нового реализма в современной русской литературе

УДК 82.02

DOI: $10.21779 / 2542-0313-2018-33-4-39-44$

\title{
Ш.А. Мазанаев
}

\section{Деконструкция постмодернизма и зарождение нового реализма в современной русской литературе}

Дагестанский государственный университет; Россия, 367001, г. Махачкала, ул. М. Гаджиева, 43a; filfak37a@mail.ru

В статье рассматриваются особенности произведений современных писателей конца XX - начала XXI в., эпохи перехода от советской литературы к постмодернизму, а впоследствии и к новому реализму. Кризис постмодернизма в русской литературе способствовал зарождению нового реализма.

В статье прослеживаются деконструкция постмодернизма на примере творчества нескольких наиболее известных авторов (Л. Улицкой, Б. Акунина, В. Сорокина) и зарождение нового реализма в современной литературе.

Рождение русского постмодернизма обычно связывают с произведениями А. Битова «Пушкинский дом», Венедикта Ерофеева «Москва-Петушки» и С. Соколова «Школа для дураков». Постмодернистские тенденции проявились также в современной русской поэзии и драматургии. Культовым произведением постмодернистской литературы справедливо считают «Москва-Петушки» Вен. Ерофеева. В статье дана характеристика наиболее ярких проявлений постмодернистских тенденций в этой поэме.

В недрах постмодернизма зарождается новое направление, которое исследователи современной русской литературы назвали новым реализмом. Новый реализм - некий мостик между художественными направлениями, этап перехода от советской литературы к новому периоду русской литературы начала XXI века. Это продолжение традиций русской литературы в новом времени, связующее звено между литературой ХХ и XXI вв.

Новый реализм создается авторами талантливыми, самобытными, и это вселяет уверенность, что они на пути обретений и находок.

Ключевые слова: постмодернизм, лирика, проза, эпоха реализм, направление.

Рождение русского постмодернизма обычно связывают с произведениями А. Битова «Пушкинский дом», Вен. Ерофеева «Москва-Петушки» и С. Соколова «Школа для дураков». В поэзии постмодернистские тенденции отмечены у представителей московского концептуализма Д. Пригова, Л. Рубинштейна, Т. Кибирова, а также в поэзии необарокко И. Жданова, Е. Шварца, А. Еременко, А. Парщикова.

Постмодернистские черты проявлялись также в лирике С. Гандлевского, Н. Искренко, И. Иртеньева, В. Вишневского, В. Салимона, В. Друка, В. Некрасова. 
Мазанаев Ш.А. Деконструкция постмодернизма и зарождение нового реализма в современной русской литературе

В современной драматургии как постмодернисты проявили себя Н. Коляда, Н. Садур, А. Шипенко, В. Гремина, Е. Гришковец, М. Угаров, М. Арбатова, М. Курочкин, В. Сигарев, О. Михайлов, Е. Исаев, К. Драгунская, О. Мухина, В. Леванов, Н. Вырыпаев, В. Пресняков, О. Пресняков, К. Костенко.

Наиболее плодотворные поиски постмодернистских тенденций и приемов мы видим у прозаиков конца XX - начала XXI в. Это общепризнанный факт. Достаточно вспомнить произведения В. Пелевина, Вен. Ерофеева, В. Сорокина, Д. Галковского. С. Гандлевского, О. Ермакова, А. Уткина, А. Королева, Ю. Буйды, М. Бутова, А. Сергеева, Т. Толстой, Л. Петрушевской, Н. Садур, В. Нарбиковой, М. Харитонова, В. Маканина, Ю. Мамлеева и многих других авторов, хотя принадлежность отдельных их текстов к постмодернизму вызывает немало вопросов. Несмотря на это постмодернизм в конце XX - начале XXI в. в русской прозе занял прочные позиции. Но уже в самом начале первого десятилетия XXI века постмодернизм, достигнув пика своего развития, начал сдавать свои позиции. Исследователи этого периода русской литературы стали отмечать усталость, стагнацию и даже исчерпанность этого литературного течения.

Культовым произведением постмодернистской литературы в современной русской прозе вполне справедливо считается поэма Венедикта Ерофеева «Москва-Петушки». При всей популярности творчества Ерофеева и кажущейся изученности поэмы «Москва-Петушки» этот текст остается нерасшифрованным до конца и даже загадочным. Сам автор адресовал текст читателям разного уровня восприятия. Самый глубокий уровень рассчитан на элитарного читателя с тонкой филологической культурой и широкой эрудицией. Не случайно при поверхностном изучении поэмы (даже читатели с определенной литературной подготовкой) упрекают автора в заимствовании сюжетных мотивов. Аллюзии, реминисценции, цитаты Венедикта Ерофеева - признаки, черты постмодернистской прозы.

Новый мир, созданный в поэме, противоположен старому, который, как правило, изображен иронично.

Жизнь, похождения, путешествие Венички изображены по законам карнавализации, травестирования. А пьянство главного героя, названного собственным именем автора, описывается как некий ритуал и физическое действо. Формы выражения авторского присутствия в поэме многообразны и отражаются не только в имени героя.

При этом размышления и рассуждения переданы в форме «болтовни» и многословных излияний бражничающего Венички. Критики, которые прочитали поэму по-новому, уже заметили, что в этой «болтовне» нет ничего лишнего: все выверено, гармонично и органично и имеет глубокий подтекст.

Все произведение Венедикта Ерофеева проникнуто ощущением абсурдности бытия «иронической эпохи», начавшейся в конце 50-х годов ХХ в. Автор удивительным образом сумел связать нить времен. При этом поиск героем спиртного становится ведущим лейтмотивом. И путь героя, с одной стороны, превращается в своеобразный карнавал, а с другой - в пародию. 
Мазанаев Ш.А. Деконструкция постмодернизма и зарождение нового реализма в современной русской литературе

Тем не менее, в постмодернистской прозе создавались тексты разного уровня и масштаба. В частности, в отдельных текстах В. Маканина, Л. Улицкой, Б. Акунина были сильны традиции реализма и классической русской литературы. Их тексты не вписывались в рамки, обозначенные для постмодернистской литературы.

В этом плане любопытны наблюдения над прозой Л. Улицкой. Людмила Улицкая пришла в литературу, будучи известным ученым-биологом. Она окончила биологический факультет МГУ, в 70-е годы уволили из института общей генетики. На протяжении многих лет писала очерки, пьесы, занималась переводами стихотворений с монгольского языка. Наиболее известные произведения «Медея и ее дети», «Сонечка», «Девочки», «Бедные родственники», «Казус Кукоцкого», «Даниэль Штайн, переводчик». В произведении «Сонечка» писательница рассказала об уникальной личности, которую можно отнести к редкому типу праведниц. Она считает себя несчастной, обманутой, покинутой. Во многих ее произведениях поднимаются нравственные проблемы («Медея и ее дети», «Искренне ваш, Шурик») и трудно выделить черты традиционно модернистского стиля. Улицкой не свойственен ярко выраженный автобиографизм, хотя в некоторых произведениях можно обнаружить отдельные факты из ее жизни. Чаще всего автор передает своим героям не факты собственной жизни, а свои мысли, настроения, философские наблюдения.

Борис Акунин - русский писатель, ученый-японист, историк и литературовед (настоящее имя Григорий Шалвович Чхартишвили). Пишет увлекательно, живо, реалистично не только в стиле постмодернизма, но и в жанре исторической литературы.

Исторические и псевдоисторические произведения Акунина отличаются особой достоверностью, что обусловлено не только талантом писателя, но и его обширными знаниями.

Серия повестей и романов детективного характера «Приключения Эраста Фандорина» принесла Акунину славу и признание. В числе первых произведений нового формата стал роман «Азазель». В цикле книг о Фандорине автор экспериментирует с различными поджанрами детектива. Например, «Левиафан» - это герметический детектив (то есть действие происходит в замкнутом пространстве, а круг подозреваемых четко очерчен), а следующий за ним «Смерть Ахиллеса» представляет собой великосветский детектив, «Азазель» - конспирологический детектив, «Турецкий гамбит» - шпионский детектив, «Коронация» великосветский детектив, «Статский советник» - политический детектив.

Несколько романов известного беллетриста были экранизированы. Среди них «Азазель», первая книга об Эрасте Фандорине, и «Пелагия». Большой популярностью пользуются фильмы «Турецкий гамбит» и «Статский советник», посвященные необычной жизни Фандорина. Тринадцатой книгой известной серии «Новый детективъ» стал роман «Весь мир театр».

Не случайно Борис Акунин называет себя беллетристом. И почти все его известные произведения о Фандорине - игра в «классики». И классичность их обманчива, иллюзорна. 
Мазанаев Ш.А. Деконструкция постмодернизма и зарождение нового реализма в современной русской литературе

Разрушению, деконструкции современного постмодернизма в немалой степени содействовала проза Владимира Сорокина. Произведения В. Сорокина шокировали читателя. При этом сам автор активно поддерживает такое мнение, считая, что его тексты не для массового читателя. Мастер имитации разных стилей Владимир Сорокин создает прозу, где соседствуют абсурд и хаос, соединение ужасного и смешного, высокого и низкого. Почти все тексты писателя построены на совмещении несовместимого. Его тексты плохо цитируются. Он постоянно вторгается в запретные темы, сферы. Исследователи отмечали, что в произведениях В. Сорокина предпринята попытка лишить человека звания Человек.

При этом произведения В. Сорокина пользуются огромной популярностью. В СМИ сообщили, что группа писателей выдвигала Сорокина на Нобелевскую премию. Будучи ярким представителем постмодернизма, Сорокин своими крайне напряженными текстами разрушает метод изнутри. Несомненно, В. Сорокин пером владеет мастерски. При этом сам текст, язык и стиль его произведений шокируют неискушенного читателя и в то же время вызывают скандальный интерес к писателю. Его «Голубое сало», «Тридцатая любовь Марины», «День опричника», «Норма», «Сердца четырех», с одной стороны, развивают постмодернистские тенденции современной прозы. Атакуя модернизм, Сорокин попадает по своему же концептуализму: его тексты оказываются самопародией. От распада конструкцию романов спасает мифологизм.

Постмодернизм продолжает своё развитие. В то же время в его недрах зарождается новое направление. Исследователи современной русской литературы назвали его новым реализмом.

Павел Басинский впервые новыми реалистами назвал Олега Павлова, Алексея Варламова, Петра Алешковского, Сергей Василенко. Из горнила постмодернизма русская литература вновь возвращается к реализму... к реализму в высшем смысле этого слова. У новых реалистов есть неприязнь:

1) с одной стороны, к шестидесятникам, на которых держится советская литература;

2) с другой стороны, к постмодернистам, окончательно скомпрометировавшим себя. Их иногда называют лево-правыми радикалами «ШаргуновоСенчинская команда». Сам Роман Сенчин новыми реалистами называет Новикова, Гуцко, Шаргунова, Кочергина, Карасева, Мамаеву, Кошкину, Ефимова, Денежкину, Бабченко.

Другие исследователи и писатели этот ряд дополняют, сокращают, корректируют. Появляются новые имена, произведения. Как и любое современное литературное явление, новый реализм изменяется, наполняется новыми именами и текстами.

Новый реализм в современной русской литературе - некий мостик между художественными направлениями, этап перехода от советской литературы к новому периоду русской литературы начала XXI века. Это продолжение традиций русской литературы в новом времени, связующее звено между литературой $\mathrm{XX}$ и XXI веков. 
Мазанаев Ш.А. Деконструкция постмодернизма и зарождение нового реализма в современной русской литературе

Это направление называют по-разному: постреализмом (Н. Лейдерман, М. Липовецкий), радикальным реализмом (С. Беляков), трансметареализмом (Н. Иванова), неореализмом, левым реализмом, трансавангардом и т. д.

Среди наиболее ярких представителей нового реализма - имена крайне разнородных современных авторов, например Захара Прилепина и Дмитрия Быкова. Одни из них придерживаются левых взглядов, другие - наоборот, либеральных.

Новый реализм представлен не только очень узнаваемыми авторами с подчеркнутым русским акцентом (Захар Прилепин, Сергей Шаргунов, Денис Гуцко, Роман Сенчин), но и молодыми писателями, создающими русскоязычные тексты с кавказским и татарским контекстом (Герман Садулаев, Алиса Ганиева, Гузель Яхина). Здесь соседствуют ультрашоковый текст Анны Козловой и абсолютно реальный мир героев Романа Сенчина.

О новых реалистах сегодня пишут и искушенные опытом известные литературные критики (С. Чупринин, Н. Лейдерман, М. Липовецкий, Н. Иванов) и молодые критики, которые порою дают крайние оценки представителям нового направления (А. Рудалев, И. Фролов, Е. Погорелая, В. Пустовая, С. Шаргунов, Д. Колесников).

Новый реализм создается авторами ищущими, талантливыми, самобытными. И есть надежда, что это направление молодых современных авторов на пути новых находок и достижений.

\section{Литература}

1. Басинский П. «Как сердцу высказать себя?». О русской прозе 90-х годов // Новый мир. - 2000. - № 4. - С. 185-192.

2. Иванова Н. Преодолевшие постмодернизм // Знамя. - 1998. - № 4. C. 193-204.

3. Калита И.В. Дело о «новом реализме» // Вопросы литературы. - 2015. № 6. - С. 123-139.

4. Колесников Д. В защиту нового реализма // Литературная Россия. - 2010. - № 34-35.

5. Мазанаев Ш.А. Русская литература ХХ века: пособие для студентов и абитуриентов филологических факультетов. - Махачкала, 2004. - 70 с.

6. Мазанаев Ш.А., Бабаева А.М. «Синдром Петрушки» Дины Рубиной как роман-метафора // Вестник ДГУ. - 2018. - Вып. 1. - С. 45-51.

7. Погорелая Е. Промежуточные итоги // Вопросы литературы. - 2015. № 6. - C. 120-122.

8. Рудалев $A$. Брань с пустотой. Основной сюжет русской культуры // Наш современник. - 2014. - № 12. - С. 198-201.

9. Скоропанова И.С. Русская постмодернистская литература. - М.: Флинта: Наука, 2002. - 608 с.

10. Фролов М. Чудище стозевно и безъязыко. Новый реализм как диктатура хамства // Литературная газета. - 2010. - № 11. 
Мазанаев Ш.А. Деконструкция постмодернизма и зарождение нового реализма в современной русской литературе

11. Шаргунов С. Отрицание траура // Новый мир. - 2001. - № 12. - С. 179184.

Поступила в редакиию 23 ноября 2018 г.

UDC 82.02

DOI: $10.21779 / 2542-0313-2018-33-4-39-44$

\section{Deconstruction of postmodernism and the emergence of a new realism in modern Russian literature}

\section{Sh.A. Mazanaev}

Dagestan State University; Russia, 367001, Makhachkala, M. Gadzhiev st., 43a; filfak37a@mail.ru

This article is devoted to the features of works by contemporary writers of the late 20th and early 21 st centuries, the era of the transition from Soviet literature to postmodernism, and subsequently to new realism. The crisis of postmodernism in Russian literature gives rise to a new realism.

The article traces the deconstruction of postmodernism on the example of the works of several of the most famous authors (L. Ulitskaya, B. Akunin, V. Sorokin) and the emergence of a new realism in modern literature.

The birth of Russian postmodernism is usually tied to the works of A. Bitov "Pushkin House", V. Yerofeev "Moscow-Petushki" and S. Sokolov "School for Fools". Postmodernist tendencies were also manifested in modern Russian poetry and drama. "Moscow-Petushki" by V. Yerofeev is rightly considered to be a cult work in the postmodernist literature. The article describes the most striking manifestations of postmodern tendencies in this famous poem.

Postmodernism continues its development. At the same time, a new direction is emerging in its depths, which studies modern Russian literature called "new realism". New realism is a kind of bridge between artistic trends, a stage of transition from Soviet literature to a new period of Russian literature at the beginning of the twenty-first century. This is a continuation of the traditions of Russian literature in the new time, a link between the literature of the $\mathrm{XX}$ and XXI centuries.

New realism is created by talented and original authors. The article expresses confidence that this is the direction of young contemporary authors on the path of acquisitions and finds.

Keywords: postmodernism, lyrics, prose, the era of realism, direction.

Received 23 November, 2018

44

Вестник Дагестанского государственного университета.

Серия 2. Гуманитарные науки. 2018. Том. 33. Вып. 4 